\title{
EDITORIAL \\ Entrepreneurship Research: Follow the Yellow-Brick Road?
}

\section{PATRICIA DOYle CoRner}

Faculty of Business, Auckland University of Technology, Auckland, New Zealand

\section{Kathryn PAVLOVICH}

Waikato Management School, University of Waikato, Hamilton, New Zealand

$\coprod_{\text {tice }}^{\text {f }}$ f entrepreneurship theory, research, and practice represent $\mathrm{Oz}$ at the culmination of the yellow-brick road, Dorothy and her companions have much company on their journey. For example, one source estimates that 460 million people worldwide either start a new business or become the owners of new businesses annually (Reynolds et al. 2002). Moreover, entrepreneurship is the fastest growing field of study in tertiary education in North America and Europe (Bygrave 2004) and fifteen specialized scholarly journals disseminate research on the topic globally. Within the policy-making arena, the governments of both Australia and New Zealand seek to promote entrepreneurship as an engine of economic growth. This special issue on entrepreneurship thus appears to be timely and can help to take stock of this topic within our Australasian context. It can also serve as a baseline from which to consider directions for future research in this important area of inquiry.

Historically, research on entrepreneurship has been informed by multiple disciplines. The influence of economics is seen through the ideas of Schumpeter (1976) and Kirzner (1997) especially. For example, Schumpeter's notion of creative destruction described how existing product markets are destroyed by entrepreneurs who create new markets from information asymmetries or other market disequilibria. Contributions from psychology have focused on explaining entrepreneurship as a function of core human characteristics including tolerance for ambiguity (Schere 1982) and need for achievement (McCelland 1961). The discipline of sociology identified properties of the broader external environment that appear to influence the likelihood of entrepreneurial activity occurring. These include competence-destroying technological change (Tushman \& Anderson 1986), industry dynamics (Hannan \& Freeman 1987), and market structures (Acs \& Audretsch 1990).

Management research has drawn on these interdisciplinary findings to inform its scholarship on the phenomenon of entrepreneurship. Despite several classic contributions, entrepreneurship research is still seen as being in its early stages of development. This 'early stage' view is expressed in articles describing the 'distinctive domain of entrepreneurship research' (Venkataraman 1997) and the 'promise of entrepreneurship as a field of research (Shane \& Venkataraman 2000). Despite its newness, however; a conceptual framework for this important field of inquiry is emerging within the management discipline. The framework holds that entrepreneurship research: 1) evaluates people who discover, assess, and exploit opportunities; 2) investigates meth- 
ods used by entrepreneurs to identify and exploit opportunities; and 3) evaluates the effects of entrepreneurship on wider society (Venkataraman 1997; Shane 2002). We use this conceptual framework as a point of departure to highlight several key issues in the domain of entrepreneurship research that we see as needing to be addressed and to highlight the contributions of the research published in this special issue.

\section{KEY ISSUE: THEORY DEVELOPMENT}

The field of entrepreneurship has been criticised from both within and without for lacking strong theoretical development (Shane 2003; Shane \& Venkataraman 2000; Venkataraman \& Sarasvathy 2001; Davidsson et al. 2001; Coviello \& Jones 2004). We advocate theory development in two related areas to complement the theory development currently being done within the discipline on an array of topics including entrepreneurial failure (Shepherd 2003), entrepreneurial cognition (Mitchell et al. 2007), and a creation view of entrepreneurial opportunities (Alvarez \& Barney 2005).

First, we recommend theory development at multiple levels of analysis in the domain of entrepreneurship. The levels of analysis common to organizational research are the individual, group, and organization. The individual level of analysis dominates empirical studies of entrepreneurship such that scholars have studied how the attributes of individual entrepreneurs, such as risk propensity, need for achievement, and locus of control, might be related to exploiting opportunities which others either didn't see or chose not to pursue (Venkataraman 1997). The reader is referred back to the conceptual framework for the field, presented in an earlier paragraph and advocated by Shane (2003) and Venkataraman (1997), as further evidence of dominance of the individual level of analysis in entrepreneurship research. However, this individual level focus limits researchers' understanding of entrepreneurial activity taking place at more collective levels of analysis. Scholars have approached but not directly addressed this collective level through ideas such as intrapreneurship (Burgelman \& Sayles 1986) and entrepreneurial orientation (Dess, Lumpkin \& Covin 1997). These ideas get at innovative behavior within collectives, specifically at the group and organizational levels. The time thus seems right to extend ideas such as opportunity identification and exploitation to levels of analysis beyond the individual. This is especially true given the theoretical tools that have recently become available for doing so (see Chan 1998; Klein \& Kozlowski 2000; Chen et al. 2004). In particular, these multi-level tools provide specific guidelines for developing collective constructs at the group and organizational level that are analogous to individual level constructs. A researcher could thereby extend the construct of opportunity identification from the individual entrepreneur level to that of a new venture team by using one of the mechanisms researchers hypothesize to be at work when an individual level construct manifests an analogous property at the group level (see Kozlowski \& Klein 2000). The actual construct of collective entrepreneurship has been touched on (see Corner \& Pavlovich 2005; West 2007) but has not been explicitly defined and described consistent with the multi-level techniques now available in the literature. Such a lack of construct development limits comprehensive theory exposition and testing in the entrepreneurship domain (Kozlowski \& Klein 2000). In particular, further development of a collective level entrepreneurship construct is likely to extend our understanding of how collective entrepreneurship unfolds. What is the mechanism whereby a new collective comes together to pursue entrepreneurial opportunities? What role does context play in the emergence of collective entrepreneurial endeavor? Are there differences between individual and collective level entrepreneurship? In order to achieve a more comprehensive understanding of this city of $\mathrm{Oz}$ that is entrepreneurship theory and practice it makes sense to explore it on all levels at which it occurs. So far, the yellow brick road we trod as 
researchers has been perhaps a bit too focused on the romantic notion of the individual, hero entrepreneur like Richard Branson of Virgin. The Luke, Verreynne, and Kearins paper in this special issue begins to address some of these multilevel issues and research questions but we suggest more is needed for a comprehensive understanding of the complete process of entrepreneurship happening at multiple levels.

Second, we recommend exploring knowledge as if it is an entrepreneurial opportunity and consider issues such as how it is created, how and when it is identified as potentially profitable, and how is it exploited by knowledge entrepreneurs. Knowledge has long been seen as a key to developing competitive advantage and much research has explored how knowledge is absorbed or acquired by a firm (Grant \& Baden-Fuller 2005; Lant \& Mezias 1992; Spender 1996). However, the bulk of this research assumes that such knowledge already exists so that the key issue is knowledge transfer - how to transfer existing knowledge from one department to another or from one company to another (Cohen \& Levinthal 1990). However, scholars are beginning to consider how new knowledge is created through a 'learning how to learn' process (Lubatkin, Florin \& Lane 2001; Pavlovich \& Corner 2006). An entrepreneurial firm must not only possess knowledge but, to gain and sustain competitive advantage, it must also have a proprietary understanding of what the information means to the firm's long term viability (Simsek \& Lubatkin 2003; Spender \& Grant 1996). Thus another area of future research in the domain of entrepreneurship is to examine how entrepreneurial firms' administrative and technical systems support and leverage unique knowledge-bases.

Finally, insight into future entrepreneurship theory development may be gained by considering the predominant reason given for its deficiency - a focus on the practitioner, in this case the entrepreneur. Stated differently, academics are accused of foregoing theory development in an attempt to make entrepreneurship research practice-relevant (Davidsson et al. 2001). While practice-relevancy is an important consideration for entrepreneurship research, a strong focus on practice may have produced knowledge that is highly context specific or grounded in a particular opportunity or new venture. Such knowledge would have limited relevance across the multiple contexts (all opportunities and new ventures) required for the generalized 'laws' that comprise theory. Achieving a balance between theory development and practice relevancy has always been a challenge for management scholars but a new mode of inquiry offers practical solutions that can help researchers attempting to create such a balance. The mode of inquiry and its promise for theory development is described in the next section.

\section{KEY ISSUE: RESEARCH METHODS}

The domain of entrepreneurship is ripe for methodological innovation and development given its relative newness as a discipline. Moreover, the extent to which knowledge can be built in any academic discipline is a function of the research methods applied while investigating the discipline. It is not surprising then that several journals have offered special issues on the topic of research methods in entrepreneurship. We agree that methodological development in the field is acutely needed. We thus offer two suggestions regarding methodological innovations within the discipline.

The first is to encourage the use of a mode of inquiry known as engaged scholarship. Engaged scholarship is a means by which academics and practitioners co-produce knowledge that can advance both theory and practice (Van de Ven \& Johnson 2006; Van de Ven 2007). It involves a process of 'intellectual arbitrage' wherein scholars and practitioners explore their differences in knowledge on a particular topic and, in a dialectic inquiry fashion, create a synthesis from the differences. For example, practitioners and academics may have different ideas about how, 
when, and where entrepreneurial opportunities occur. Engaged scholarship would have academics and practitioners explore these differences and generate propositions informed by the discrepancies. Such differences can lead to two sets of competing propositions to test (one set hypothesized by academics and one set developed by practitioners) or to a mid-range set of testable propositions anchored partway between the context-free realm of theory and the completely context dependent realm of practice (Van de Ven 2007).

In applying engaged scholarship, future theory in the domain of entrepreneurship may truly become 'practice-informed' in that practice shapes theory from the very outset of theory development - through the formulation of broad and important research questions formulated to solve real world problems. Moreover, entrepreneurial practice is likely to benefit in that potential entrepreneurs get help with weighty problems that they do not have the time or the resources to resolve themselves. We thus encourage entrepreneurship scholars to consider using engaged scholarship as a mode of inquiry that provides a structure with the potential to bridge the theory/ practice 'divide'. We advocate this mode as a means by which a practitioner focus can enrich theory while continuing to address the perspective of the 'real-world' entrepreneur. If destination $\mathrm{Oz}$ is going to truly have both theory and practice components, perhaps we academics need to be more conscious of integrating theory and practice 'traffic' on our yellow brick road through bridging structures and merging lanes as suggested by the engaged scholarship mode of inquiry.

A second suggestion is to apply research methods that are able to capture the complexity and richness of entrepreneurial phenomena better than the prevailing positivist approach to investigating this field (Coviello \& Jones 2004). Specifically, we suggest the use of qualitative evidence to generate rich theory grounded in the experience of actual entrepreneurs. The use of such evi- dence seems particularly important given the agreed upon lack of theory in the literature. Building theory from evidence seems preferable to building theory from a literature that many scholars see as conceptually impoverished. Perhaps we academics turned to positivist methods prematurely in the early stages of this developing discipline. The good news is that qualitative evidence is being applied to the topic of entrepreneurship more frequently in the literature and includes specific methods such as phenomenology (Cope 2005); constructivism (Hill \& McGowan 1999); a critical approach (Huse \& Lundstrom 1997); and a blending of interpretivist and positivist approaches (Coviello \& Jones 2004). Moreover, the use of such qualitative evidence fits in nicely with the use of engaged scholarship.

\section{SPECIAL ISSUE ARTICLES}

This special issue on Australasian Entrepreneurship presents six very diverse articles on the topic. The first article by Hunter and Wilson illustrates the roots of entrepreneurship in New Zealand. The authors examine the origins of New Zealand entrepreneurs for the period 1840 to 1990 and explore the differences between entrepreneurial history in New Zealand, the UK, and the United States. The findings illuminate the family and educational backgrounds of historical New Zealand entrepreneurs as well as provide insight into the financing used and business strategies followed by $19^{\text {th }}$ and $20^{\text {th }}$ Century business founders. The article provides a useful grounding for researchers wishing to understand current and future trends in entrepreneurial actions in New Zealand and where these trends may have come from.

The second article, by Luke, Verreynne and Kearins, shifts the focus to the future and presents a set of guidelines for investigating the benefits of entrepreneurship. These guidelines take the form of four boundary conditions that can potentially clarify understanding of entrepreneurial benefits regardless of context (new or estab- 
lished firm), firm size (small or large), or level at which entrepreneurship takes place (individual entrepreneur or new venture entrepreneurial team, for example). Moreover, the authors provide a comprehensive summary of measures that may be used to capture entrepreneurship's benefits across multiple levels of analysis, from the individual entrepreneur to the level of a nation hoping to benefit from encouraging entrepreneurship.

The third article explores entrepreneurial failure and how entrepreneurs coped with the loss of their ventures. While most entrepreneurship research focuses on entrepreneurial success, Singh, Corner and Pavlovich argue that it is important to consider the phenomenon of failure to get a comprehensive view of the phenomenon of entrepreneurship. Singh et al collect qualitative evidence to assess how entrepreneurs coped with failure in four key areas of their lives: economic, psychological, physiological and social. Findings suggest that entrepreneurs coped best with the economic aspects of failure and shed light on the connection between coping with and learning from failure.

The article by Weaven, Isaac and Herington explores the factors influencing female entrepreneurs in Australia to enter self employment as either franchisees or independent small business owners. The current literature suggests that franchising reduces the psychological and performance risk of entering self-employment through minimising capital, experiential and managerial barriers. One of the findings from the 14 franchises and 12 small business owners interviewed suggested that independent, non-franchised business owners appeared to value intrinsic rewards and consciously limited the size of their organisations so as to manage their work-life balance more proactively. Conversely, those opting for franchises were more motivated by extrinsic factors such as wealth and status. This lack of orientation towards more work-life balance may indicate why there are difficulties in Australia in attracting franchise holders.
The next paper describes a study by Kirkwood on Tall Poppy Syndrome (TPS) and how it applies to entrepreneurs in New Zealand. She found that over half the 40 interviewees indicated that they purposefully chose not to flaunt their wealth as a result of experiencing envy or hostility from their success. This included not telling others that they owned their own business, not taking their expensive car to work, and keeping their [affluent] place of residence secret. These findings suggest that an interesting tension exists in New Zealand wherein the Global Entrepreneurship Monitor (GEM) reports it as the country having the most opportunity for entrepreneurship, but where successful entrepreneurs feel somewhat uncomfortable with that success. Findings thus call into question the extent to which: 1) New Zealand culture values entrepreneurial success; and 2) the country can put forward role models that display the hard work and risk taking that underlies successful business creation.

The final paper by Yim and Weston harks back to the body of entrepreneurship research that tried to distinguish entrepreneurs from nonentrepreneurs through a set of distinguishing characteristics. In this pilot study, the authors link personality traits and personality types to start-ups in Australia's biotech industry. They find a predominance of certain personality types in this industry and also conclude that the biotech industry has strong demands for entrepreneurs with managerial skills, sales and marketing skills, skills in forming strategic alliance with partners and skills in securing the public and private capital through finance channels such as public listing and venture capital.

On a final note, we would like to thank the authors for all their hard work in revising the manuscripts for the special issue. We have found taking a few steps down the yellow brick road with you to be a rich and rewarding experience. We were impressed with the extent to which the authors engaged with the reviewers' and editors' feedback. The selection of papers in this issue represents an acceptance rate of $35 \%$. 


\section{References}

Acs Z \& Audretsch D (1990) Small firm entry in US manufacturing, Economica, 56: 255-266.

Alvarez SA and Barney J (2005) Discovery and Creation: Implications for practice and policy. Paper presented at the 2005 Enterprise and Innovation Research Conference, Waikato Stadium: Hamilton, New Zealand.

Bygrave W (2004) 'The entrepreneurial process' In Bygrave W and Zarcharakis A (Eds) The Portable $M B A$ in Entrepreneurship, $3^{\text {rd }}$ edn. Hoboken: John Wiley \& Sons (pp 1-28).

Burgelman R and Sayles L (1986) Inside corporate innovation: Strategy, structure, and managerial skills. New York: The Free Press.

Chan D (1998) Functional relations among constructs in the same content domain at different levels of analysis: A typology of composition models. Journal of Applied Psychology 83: 234-246.

Chen G, Mathieu J and Bliese P (2004) 'A framework for conducting multilevel construct validation' in Yammarino F and Dansereau F (Eds) Research in multi-level issues 3: 273-303 London, Elsevier.

Cohen WM and Levinthal DA (1990) Absorptive capacity: A new perspective on learning and innovation. Administrative Science Quarterly 35: $128-152$.

Cope J (2005) Researching entrepreneurship through phenomenological inquiry: Philosophical and methodological issues. International Small Business Journal 23: 163-189.

Corner P and Pavlovich K (2005) Collective Entrepreneurship: Construct Definition and Development. Proceedings of the AGSE (Entrepreneurship Research Exchange), Auckland: Unitec.

Coviello N and Jones M (2004) Methodological issues in international entrepreneurship research. Journal of Business Venturing 19: 485-508.

Davidsson P, Low M, Wright M (2001) Editor's introduction: Low and MacMillan ten years on: Achievements and future directions for entrepreneurship research. Entrepreneurship Theory \& Practice, Summer, 5-15.

Dess G, Lumpkin G and Covin J (1997) Entrepreneurial strategy making and firm performance:Tests of contingency and configuration models. Strategic Management Journal 18: 677-695.

Grant R and Baden-Fuller C (2004) A knowledge accessing theory of strategic alliances. Journal of Management Studies 41: 61-85.
Hannan M and Freeman J (1987) The ecology of organizational founding: American labor unions, 1836-1975. American Journal of Sociology 92: 910-943.

Hill J and McGowan P (1999) Small business and enterprise development: questions about research methodology. International Journal of Entrepreneurial Research 5: 5-13.

Huse M and Landstrom H (1997) European entrepreneurship and small business research: methodological openness and contextual differences. International Studies of Management and Organizations 27 (Fall): 3-12.

Khilstrom R and Laffont J (1979) A general equilibrium entrepreneurial theory of firm formation based on risk aversion. Journal of Political Economy 87: 719-748.

Kirzner I (1997) Entrepreneurial discovery and the competitive market process: An Austrian Approach, Journal of Economic Literature XXXXV (1) March: 60-85.

Klein K and Koslowski S (2000) Multilevel theory, research, and methods in organizations: Foundations, extensions, and new directions. San Francisco: Jossey-Bass Inc.

Koslowski SWJ and Klein K (2000) 'A multilevel approach to theory and research in organizations: Contextual, temporal, and emergent processes' in Klein K and Koslowski SWJ (Eds) Multilevel theory, research, and methods in organizations: Foundations, extensions, and new directions pp 390. San Francisco: Jossey-Bass.

Lant TK and Mezias SJ (1992) An organizational learning model of convergence and reorientation. Organization Science 3: 47-72.

Lubatkin M, Florin J and Lane P (2001) Learning together and apart: A model of reciprocal interfirm learning. Human Relations 54(10): 1353-1382.

McClelland D (1961) The Achieving Society. Princeton, NJ: Van Norstrand.

Mitchell R, Busenitz L, Bird B, Gaglio C, McMullen J, Morse E and Smith JB (2007) The central question in entrepreneurial cognition research 2007. Entrepreneurship, Theory, and Practice 31: 1-27.

Pavlovich K and Corner P (2006) Knowledge Creation Through Co-Entrepreneurship. International Journal of Knowledge Management Studies 1: 178-196.

Reynolds P, Bygrave W, Autio E and Hay M (2002) Global Entrepreneurship Monitor-2002 Summary Report available at www.gemconsortium.org. 
Schere J (1982) Tolerance of ambiguity as a discriminating variable between entrepreneurs and managers. Academy of Management Best Paper Proceedings 42: 404-408.

Schumpeter J (1976) The process of creative destruction, in Capitalism, Socialism, and Democracy. Chapter VII, London: George Allen \& Unwin, pp 81-86.

Shane S and Venkataraman S (2000) The promise of entrepreneurship as a field of research, Academy of Management Review 25: 217-226.

Shane S (2002) Introduction. The Foundations of Entrepreneurship: Volume 1. Cheltenham: Edward Elgar.

Shane S (2003) A General Theory of Entrepreneurship: The Individual-Opportunity Nexus. Cheltenham: Edward Elgar.

Shepherd DA (2003) Learning from business failure: propositions of grief recovery for the selfemployed. Academy of Management Review 28(2): 318-328.

Simsek Z and Lubatkin M (2003) Toward a knowledge-based view of entrepreneurial initiatives and performance. Working Paper, School of Business: University of Connecticut. Spender JC (1996) Organizational knowledge, learning and memory: three concepts in search of a theory. Journal of Organizational Change Management 9: 63-79.
Spender J-C and Grant R (1996) Knowledge and the firm: An overview. Strategic Management Journal 17 (Special Issue): 5-10.

Tushman M and Anderson P (1986) Technological discontinuities and organizational environments. Administrative Science Quarterly 31: 439-465.

Van de Ven A (2007) Engaged Scholarship. Oxford University Press: Oxford.

Van de Ven A (2007) Personal communication between first author and Professor Van de Ven at Academy of Management Meetings, Philadelphia, PA., USA.

Van de Ven A and Johnson P (2006) Knowledge for theory and practice. Academy of Management Review 31: 802-821.

Venkataraman S (1997) The distinctive domain of entrepreneurship research. Advances in Entrepreneurship, Firm Emergence and Growth 3: 119-138.

Venkataraman S and Sarasvathy S (2001) 'Strategy and entrepreneurship: Outlines of an untold story' in Hitt M, Freeman RE and Harrison J (Eds) The Blackwell Handbook of Strategic Management. Oxford: Blackwell (pp 650-668).

West GP (2007) Collective Cognition: When entrepreneurial teams, not individuals, make decisions. Entrepreneurship, Theory, and Practice 31: 77-78.

\section{$2008 / 2009$ CALLS FOR PAPERS}

\section{Journal of Management \& Organization (ISSN 1833 3672) special issues}

ARTFUL MANAGEMENT EDUCATION \& DEVELOPMENT

Guest edited by Cheryl Kerr and Lotte Darsø

Manuscript submission deadline - 20 December 2007

\section{FAMILY BUSINESS: THEORY \& PRACTICE}

Guest edited by Justin Craig, Carole Howorth, Ken Moores and Panikkos Poutziouris Manuscript submission deadline - 20 February 2008

CORPORATE GOVERNANCE: PRACTICE AND PROCESS

Guest edited by Gael McDonald, Jens Mueller and Clive Smallman Manuscript submission deadline - 21 April 2008

PROFITABLE MARGINS: GENDER AND DIVERSITY INFORMING MANAGEMENT AND ORGANIZATIONAL STUDIES

Guest edited by Alison Sheridan, Judith Pringle and Glenda Strachan Manuscript submission deadline - 20 July 2008

Author Guidelines are available at www.jmanorg.com. Please indicate the title of the special issue and submit to the Editor at JMOEditorial@e-contentmanagement.com eContent Management Pty Ltd, PO Box 1027, Maleny QLD 4552, Australia Tel.: +61-7-5435-2900; Fax. +61-7-5435-2911

www.e-contentmanagement.com 